\title{
Bird Banding in North America: The First Hundred Years
}

Edited by Jerome A. Jackson, William E. Davis, Jr., and John Tautin. 2008. Memoirs of the Nuttall Ornithological Club, Memoir \#15. c/o Museum of Comparative Zoology, Harvard University, Cambridge, Massachusetts 02138 USA. ix +280 pages. 45 USD. Cloth.

This, the $15^{\text {th }}$ memoir of the Nuttall Ornithological Club, is the proceedings of a day-long symposium, 26 September 2002, at the Third North American Ornithological Conference held in New Orleans. While Frank Moore's talk, "Bird banding and the study of migration," has been omitted, perhaps because the thousands of papers on the topic speak for themselves, John Tautin's paper "A History of the Bird Banding Laboratory 1920 - 2002," is an appropriate substitution.

The symposium celebrates the remarkable contributions of bird banding to ornithology. These contributions are summarized by three sentences in John Tautin's Preface: "Few, if any, tools have advanced our knowledge of birds as banding has. Few if any tools used by ornithologists have had such a history and culture with devotees, paraphernalia, organizations, publications, and lore. More than 66 million birds have been banded and 3,700,000 have been recaptured or re-sighted."

When aluminum became available in 1899, Hans Christian Mortensen marked 165 starlings in Denmark. In 1902-1903, Paul Bartsch banded 23 nestling Blackcrowned Night-Herons near Washington, D.C. From 1914 to 1916 , Alexander Wetmore banded 1241 birds in the Bear River marshes of Utah and obtained 182 recoveries. In 1920, Frederick C. Lincoln was made head of the U.S. government bird banding program. Working in close collaboration with the Canadian government, Lincoln promoted banding as "the sport which is also a Science." By the late 1920s, banding had grown by leaps and bounds and come of age as a scientific tool. The Bird Banding Laboratory, which moved from Washington to the Patuxent Refuge in Maryland during World War 2, "was, and still is, one of the longest running, most successful offices in the history of wildlife conservation."

Charles M. Francis, of the Canadian Wildlife Service, explains how the greatest value of banding data has been for monitoring avian survival rates, age ratios, productivity, recruitment and longevity. For game birds, harvest rates can be calculated. Glitches of various kinds arose, especially the severe band loss that occurred among gulls. James D. Nichols and John Tautin explain how, beginning in 1978, statistical models were developed for adult-only data and for data with both adults and young, to estimate survival and recovery rates with greater precision. These involved optimization of goodness-of-fit tests and likelihood-ratio tests. Such statistical methods have made banding an important tool for managing game hunting.

Field studies of eco-toxicology would be almost nonexistent if it were not for sophisticated controlled field studies made possible by banding. Banding studies have helped reveal whether a given population of birds is a "source" or a "sink." For example, banding showed that Brown-headed Cowbirds spend their mornings in breeding areas and their afternoons in feeding areas up to $18 \mathrm{~km}$ distant. Additionally, banding helps identify and map areas of threat to a given species. Banders also obtain fascinating and valuable scientific data about birds and their behaviour by weighing captured birds before release. For instance, banders measured the fat levels of the Semipalmated Sandpiper before its long distance migration from Massachusetts to the coast of Suriname.

Both human and avian health concerns are studied by banders who follow the avian carriers of West Nile virus, encephalitis, Lyme disease, mycoplasma, avian tuberculosis and malaria. For instance, from blood samples, they determine what percentage of Blue Jays carry which virus and what percent have antibodies, at which seasons and in what localities.

Identification of individual birds is the cornerstone of studies of bird behavior. Studies have progressed from anecdotal observations to hypothesis testing as banding provides the "best all-purpose, low-cost, and minimum-technology way to recognize individual birds in the field," and bands enable scientists to deepen their knowledge of bird behaviour and biology.

Banding has also proven itself to be an invaluable conservation tool. When species such as the Brown Pelican, Bald Eagle, Whooping Crane, Snail Kite, Red-cockaded Woodpecker, California Condor, and the Florida subspecies of the Grasshopper Sparrow showed drastic declines, banding techniques led to management practices that helped to save the species or increase its numbers.

The editors of this superb volume deserve fulsome praise, as does the Nuttall Club for making publication possible. Portraits of the leaders in banding increase the interest in this valuable compilation of a landmark conference. This book makes it clear how much ornithologists, bird lovers, and the general public have benefited from the science of bird banding.

\section{Stuart Houstin}

863 University Drive, Saskatoon, Saskatchewan S7N 0J8 Canada 